\title{
Diversity of fruit bats (Pteropodidae) and their ectoparasites in Batuputih Nature Tourism Park, Sulawesi, Indonesia
}

\author{
MEIS NANGOY ${ }^{1, \bullet}$, TILTJE RANSALELEH ${ }^{1}$, HANDRY LENGKONG $^{2}$, RONI KONERI $^{2}$, ALICE LATINNE ${ }^{3,4}$, \\ RANDALL C. KYES ${ }^{5}$ \\ ${ }^{1}$ Faculty of Animal Science, Universitas Sam Ratulangi. J1. Bahu, Manglayang, Manado 95115, North Sulawesi, Indonesia. \\ "email: mnangoy@unsrat.ac.id \\ ${ }^{2}$ Department of Biology, Faculty of Mathematics and Natural Sciences, Universitas Sam Ratulangi. Jl. Bahu, Manglayang, Manado 95115, North \\ Sulawesi, Indonesia \\ ${ }^{3}$ Wildlife Conservation Society, Viet Nam Country Program. 106, D Building, No. 3 Thanh Cong Street, Thanh Cong Ward, Ba Dinh District, Ha Noi, \\ Viet Nam \\ ${ }^{4}$ Wildlife Conservation Society, Health Program. 2300 Southern Boulevard Bronx, New York 10460, USA \\ ${ }^{5}$ Departments of Psychology, Global Health, and Anthropology, Center for Global Field Study; Washington National Primate Research Center, \\ University of Washington, Seattle, Washington, USA
}

Manuscript received: 4 March 2021. Revision accepted: 7 May 2021

\begin{abstract}
Nangoy M, Ransaleleh T, Lengkong H, Koneri R, Latinne A, Kyes RC. 2021. Diversity of fruit bats (Pteropodidae) and their ectoparasites in Batuputih Nature Tourism Park, Sulawesi, Indonesia. Biodiversitas 22: 3075-3082. Bats play an important role in the ecosystem as pollinators, seed dispersers, and predators, therefore, this study aims to identify the diversity of fruit bat species and ectoparasites at Batuputih Nature Tourism Park, Sulawesi, Indonesia. The study was conducted from May to July 2019, and carried out in three different habitats, namely primary and secondary forest, as well as agricultural land. Besides, the bats were caught using a mist net while the ectoparasites were collected and identified using morphological criteria. A total of 253 bats were sampled representing 10 species (all belonging to the family Pteropodidae) namely Cynopterus brachyotis (24.90\%), C. luzoniensis (9.88\%), Dobsonia exoleta (1.19\%), Macroglossus minimus (3.16\%), Nictymene cephalotes (4.75\%), N. minutus $(0.79 \%)$, Rousettus amplexicaudatus (17\%), R. celebensis (20.95\%), Thoopterus nigrescens (17\%), and Thoopterus sp. (0.4\%). Cynopterus brachyotis was the most abundant species (n =63). Meanwhile, a total of 479 ectoparasites were collected and identified as belonging to three families, namely Nycteribiidae, Streblidae, and Spinturnicidae. Nycteribiidae (genus Leptocyclopodia) was the most abundant ectoparasite taxa $(\mathrm{n}=475)$ while the highest mean abundance and intensity were observed for the genus Thoopterus and Rousettus. This study provides important baseline data for future reference in monitoring bat population status and conservation efforts in the region. Given the close relationship between the local people and bats (e.g. hunting and consumption), more work is needed to address the potential pathogen risks from zoonotic transmission, both from bats and the respective ectoparasites.
\end{abstract}

Keywords: Nycteribiidae, parasitism, Pteropodidae, Spinturnicidae, Streblidae

\section{INTRODUCTION}

Bats play several important roles in the ecosystem including pollination, seed dispersal, and insect predation. Despite the important contributions to the function and sustainability of the ecosystem, bats are exposed to numerous anthropogenic threats that affect survival, such as hunting (Sheherazade and Tsang 2015; Mildenstein et al. 2016). In certain regions of Sulawesi, Indonesia, fruit bats are used for human consumption (Ransaleleh et al. 2020) and as traditional medicine by local communities living near the forest. Furthermore, bats are also part of wildlife trade extending throughout majority of the island's provinces, as part of a well-organized, dynamic, and easily accessible network involving many actors (Latinne et al. 2020).

Aside from anthropogenic threats such as hunting, parasitism poses another serious threat to the health of bats. Ectoparasites in particular are known to affect the physical conditions and therefore impact the long-term viability of the population (Webber and Willis 2016). Although no direct effect of ectoparasites on bat mortality has been observed, some studies have shown that ectoparasites tend to decrease bats' fecundity. Ticks, mites, chiggers, bugs, fleas, and flies are among the types of ectoparasites discovered on bats (Almeida et al. 2011; Holz et al. 2018). Some of the ectoparasites are associated with pathogens that might cause disease in humans or animals both wild and domestic (Reeves et al. 2016). Therefore, studies on bat ectoparasites are important to determine the potential role as vectors of zoonotic pathogens (Kim et al. 2012). Moreover, flies belonging to the families Nycteribiidae and Streblidae (Hiller et al. 2020), and mites belonging to the family Spinturnicidae (Almeida et al. 2016) are hematophagous organisms, and are commonly found on bats in tropical regions.

In the last decade, a number of studies have been conducted on bat ectoparasites in several countries namely Brazil (Almeida et al. 2011), Canada (Czenze and Broders 2011), Australia (Holtz et al. 2018), Philippines (Pader et al. 2018), Singapore (Lee et al. 2018; Lim et al. 2020), and South East Asia region (Gay et al. 2014). According to 
Luguterah and Lawer (2015), frugivorous bats were more infested by ectoparasites than insectivorous bats. Some fruit-eating bats only eat part of the fruit (Dumont and O'neal 2004) while the remaining portion on the tree or which falls to the ground is then consumed by other wild animals or livestock on agricultural land. This in turn presents a potential source of pathogen transmission from bats to livestock or humans (Mikail et al. 2017). Moreover, Yang et al. (2017) reported that the bat genus, Rousettus is a reservoir for filoviruses. Rousettus and Cynopterus were also reported as reservoirs for the Marbug virus, while Cynopterus brachyotis and Macroglossus sobrinus were reservoirs for Leptospirosis (Mulyono et al. 2018).

In Indonesia, the knowledge regarding bats and ectoparasites is limited, hence, there is a need for a detailed study on bats and the potential effects of ectoparasites. This study aims to identify the diversity of fruit bats and the ectoparasites at Batuputih Nature Tourism Park (BNTP) in North Sulawesi, Indonesia, and to obtain baseline data about the status of bats in the region as a foundation for future assessment of potential zoonotic pathogen risk posed by both bats and the ectoparasites.

\section{MATERIALS AND METHODS}

\section{Study area}

This research was conducted in Batuputih Nature Tourism Park (BNTP), North Sulawesi, Indonesia from May to July 2019 (Figure 1). The BNTP is located within the Tangkoko Nature Reserve system (renamed "Tangkoko Conservation Forest Management Unit" in 2016) between

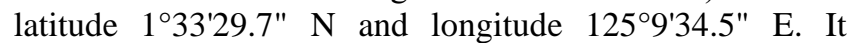
includes the Batuputih village in the North Bitung Subdistrict, Bitung City, North Sulawesi Province, Indonesia. The park is located at an altitude of $0-200 \mathrm{~m}$ above sea level with flat and slightly hilly terrain (O'Brien and Kinnaird 1996; Kyes et al. 2013 ).

The BNTP climate conditions (based on the Schmidt and Ferguson classification) (Arrijani and Rizki 2020) include climate type $B$ with an average annual rainfall ranging from $2,279 \mathrm{~mm}$ and a daily average temperature between $23-24^{\circ} \mathrm{C}$. Furthermore, the vegetation is dominated by coastal and secondary forest vegetation including species from Anacardiaceae, Burseraceae, Combretaceae, Moraceae, Sapotaceae, Thymeleaceae, Vitaceae, and others. The park has a large camping ground used for recreation and conservation education, as well as a station for field research.

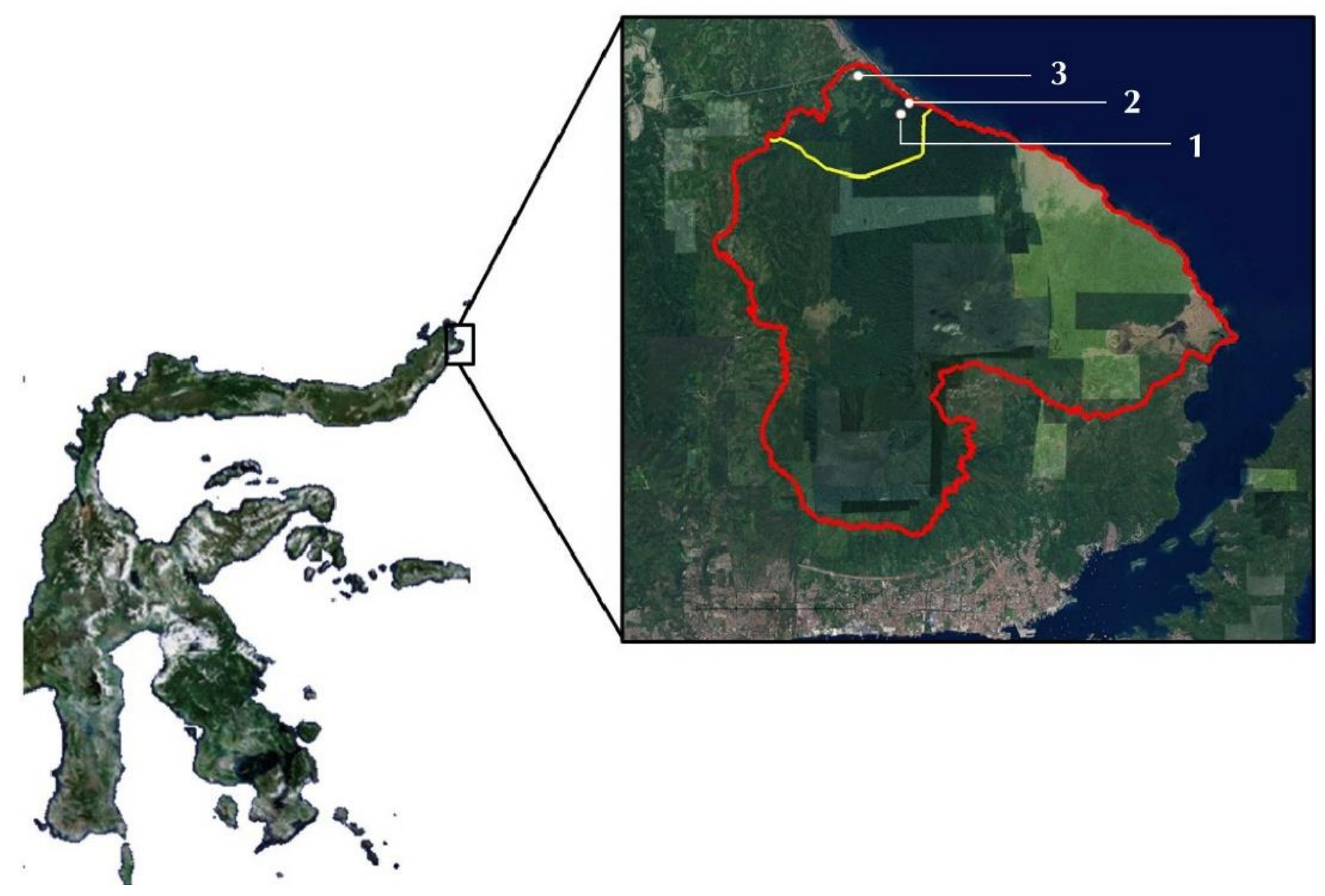

Figure 1. Map showing location of the Tangkoko Nature Reserve system (Tangkoko Conservation Forest Management Unit, outlined in red) and the Batuputih Nature Tourism Park (located at the northern tip of the reserve, within the yellow line). The three bat sampling locations are indicated by the numbers white dots: 1. Primary Forest; 2. Secondary Forest; and 3. Agricultural Land). (Courtesy: Google Earth 2020; Maxar Technologies 2020) 


\section{Sampling locations}

Three types of habitats were selected as sampling locations: primary and secondary forest, reserve, and agricultural land around the reserve. The primary forest was defined as an undisturbed habitat with trees belonging to the Anacardiaceae (Dracontomelon dao), Annonaceae (Cananga odorata), Lamiaceae (Vitex quinata), Sapotaceae (Palaqium obovatum), and Anacardiaceae (Koordersiodedron pinnatum). Meanwhile, the secondary forest consisted of regrown forest in disturbed habitat (e.g., following forest fires) and included trees belonging to the Moraceae (Ficus sp.), and Combretaceae (Terminalia catappa). Agricultural land was located at the forest fringe area, where local communities planted crops such as Anacardiaceae (Mangifera sp.), Caricaceae (Carica papaya), and Musaceae (Musa sp.). A reconnaissance survey was conducted in each habitat before the main study to identify the location of fruit bat foraging trees (bearing fruit or flowering) and flight paths as well as to determine the appropriate netting locations.

In the tropical region, fruit bats avoid foraging behavior during full moon to avoid predators (Lima and O'Keefe 2013). Therefore, netting was carried out during a new moon phase, one night per month, in each habitat for three months (May, June, and July 2019). This resulted in a total of three sampling nights in each habitat. The netting started at 06.00 PM and continued until 06.00 AM the next morning, meanwhile, the mist net was $12 \mathrm{~m}$ in length and $2.5 \mathrm{~m}$ in height, with a $15 \times 15 \mathrm{~mm}^{2}$ mesh (Shijiemesh) and was placed approximately $3 \mathrm{~m}$ above the ground. Given that fruit bats are highly dependent on fruits as a source of food, the mist nets were placed near fruit trees that are potential paths. The net was monitored every 30-45 minutes through the night and bats were collected as detected.

\section{Sampling techniques collection of bat and ectoparasite samples}

All procedures involving mist-netting, handling, and subsequent release followed the guidelines established by the Indonesian Ministry of Health Research and Development Agency (2015) to ensure the health and safety of both bats and researchers. The study protocol also was approved by the committee Research and Community Service Institutions, Sam Ratulangi University, Manado, Indonesia (1937/UN12.13/LT/2018). Captured bats were removed from the net with a gloved hand (following Mikael et al. 2017) and transferred into a cotton cloth bag for transport to the nearby processing station for morphometric measurements and identification using morphological criteria by Bergmans and Rozendaal (1988) and species of bats in Sulawesi by Yuliadi et al. (2014).

The manual collection of ectoparasites from the bat's body was carried out sequentially starting from the head, ears, neck, wing bases, base of the feet, and toes using tweezers. In addition, bats were combed carefully to collect any additional ectoparasites left in the fur. The samples were then placed in collection tubes containing $70 \%$ alcohol, meanwhile, ectoparasites from different body parts were placed in separate tubes. Before release, bats were marked on the head with a permanent marker to avoid resampling. All collected ectoparasites were subsequently sorted, identified, counted, mounted on microscope slide, and deposited for further study in the Animal Wildlife Laboratory, Faculty of Animal Science, Sam Ratulangi University. Specimens were taxonomically identified using the taxonomic keys by Baker and Delfinado (1964) and Maa (1975) under a binocular microscope. Moreover, the author (M.N.) took photographs under binocular microscope using a digital Samsung Galaxi Note 3 camera and processed with Adobe Photoshop CS4.

\section{Data analysis}

Ectoparasite abundance (i.e., mean number of parasites per host), mean intensity (i.e., mean number of parasites per infested host), and prevalence (i.e., number of infested hosts divided by total hosts sampled) (see Bush et al. 1997) were calculated using Quantitative Parasitology Software 3.0. Statistical analyses were performed to assess habitat preference of the bats and the proportion of ectoparasite infestation by gender using Bootstrap Method (SPSS version 23) due to the data not normal distribution and limit sample (Reiczigel et al. 2019). The differences between females and males were not examined for bat species with a small sample size of infested individuals $(<10)$.

\section{RESULTS AND DISCUSSION}

\section{Species and composition of bats sampled}

A total of 253 fruit bats were captured in three different habitats in BNTP. The bats were all from the Pteropodidae family, and were further identified as representing 10 species namely Cynopterus brachyotis, C. luzoniensis, Dobsonia exoleta, Macroglossus minimus, Nictymene cephalotes, N. minutus, Rousettus amplexicaudatus, R.celebensis, Thoopterus nigrescens, and Thoopterus sp. Moreover, the highest bat abundance was observed in the secondary forest, where $39.53 \%$ of the bats were captured, followed by the agricultural land with $38.34 \%$ and then primary forest with $22.13 \%$. Cynopterus brachyotis was the most abundant species captured, 63 (24.90\%), followed by Rousettus celebensis (22.57\%). The least abundant species was Thoopterus sp, with only one sample captured in the primary forest $(0.40 \%)$ (Table 1$)$. Besides, the Bootstrap Test showed that there is no significant difference in bat abundance in each habitat $(\mathrm{p}=0.634)$.

\section{Diversity of ectoparasites}

A total of 479 ectoparasites representing three families, namely Nycteribiidae, Streblidae (bat flies), and Spinturnicidae (mites) were collected. Majority of these ectoparasites $(\mathrm{n}=475)$ belonged to the family Nycteribiidae genus Leptocyclopodia and were characterized by the following morphological characteristics; body size $1.11-1.90 \mathrm{~mm}$, spider-like, dorsoventrally flat, hairy body, possess several ctenidia or combs, claws at the tips of the feet, and head attached to the thorax. The tibia was characterized by three white rings (Figure 2). A one-winged sample, discovered on the head 
of a Dobsonia bat, was identified as a member of the family Streblidae. Three members of the family Spinturnicidae were also reported on the wing of a Dobsonia bat. Meanwhile, due to lack of specimens, Streblidae and Spinturnicidae were not identified at the genus and species level.

\section{Ectoparasites and hosts}

Nycteribiidae ectoparasites were discovered on eight bat species, i.e. Cynopterus brachyotis, C. luzoniensis, Dobsonia exoleta, Macroglossus minimus, Rousettus amplexicaudatus, $R$. celebensis, T. nigrescens, and Thoopterus sp.

The highest mean abundance (2.00-3.51) and intensity (2.00-3.97) were observed in the genus Thoopterus. Meanwhile, parasite from the Spinturnicidae and Streblidae families were found only on $D$. exoleta. No ectoparasites were found on $N$. cephalotes and $N$. minutus (Table 2). The prevalence of Nycteribiide infestation in bats was highly variable among species (20.6-100\%).

\section{Ectoparasites (Nycteribiid) based on the bat gender}

The results showed that the total number of Nycteribiid ectoparasites was higher in female bats compared to males for all species identified (Table 3). However, the Bootstrap test showed that the mean intensity of ectoparasite infestation found on female bats was not significantly higher than males $(\mathrm{p}>0.05)$.

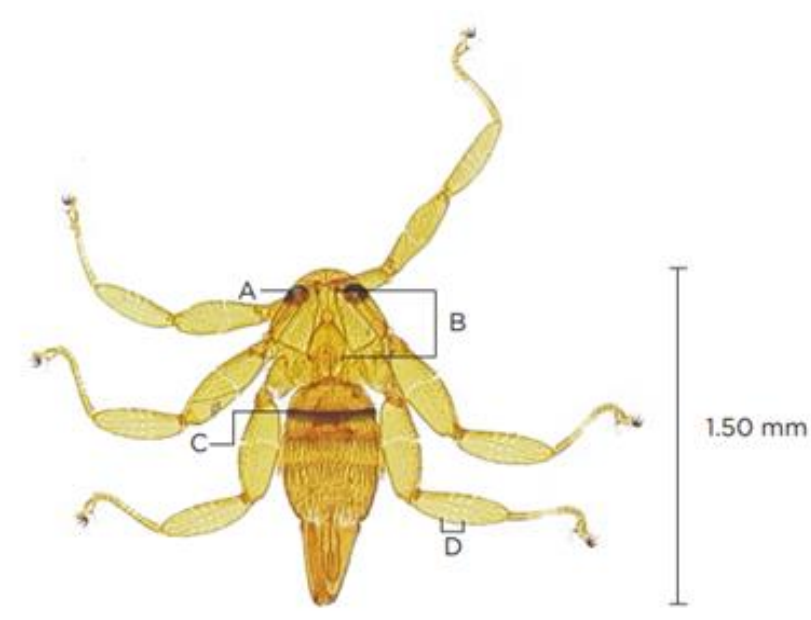

Figure 2. Leptocyclopodia ferrarii collected from Cynopterus brachyotis at Batuputih Nature Tourism Park, Sulawesi, Indonesia (2018) A ( Thorax ctenidia), B (Head), C (Abdomen ctenidia), D (Tibial rings) (Photographs by M.N.)

Table 1. Species and composition of bats sampled in the three habitat types in Batuputih Nature Tourism Park, North Sulawesi, Indonesia

\begin{tabular}{|c|c|c|c|c|c|c|c|c|c|c|}
\hline \multirow{2}{*}{ Species } & \multicolumn{2}{|c|}{ PF } & \multicolumn{2}{|c|}{ SF } & \multicolumn{2}{|c|}{$\mathbf{A L}$} & \multicolumn{3}{|c|}{ Total } & \multirow{2}{*}{$\%$} \\
\hline & $\mathbf{M}$ & $\mathbf{F}$ & $\mathbf{M}$ & $\mathbf{F}$ & $\mathbf{M}$ & $\mathbf{F}$ & $\mathbf{M}$ & $\mathbf{F}$ & Total & \\
\hline Cynopterus brachyotis & 3 & 3 & 13 & 5 & 20 & 19 & 36 & 27 & 63 & 24.90 \\
\hline Cynopterus luzoniensis & 0 & 0 & 4 & 7 & 8 & 6 & 12 & 13 & 25 & 9.88 \\
\hline Dobsonia exoleta & 0 & 0 & 1 & 2 & 0 & 0 & 1 & 2 & 3 & 1.19 \\
\hline Macroglossus minimus & 1 & 1 & 2 & 2 & 1 & 1 & 4 & 4 & 8 & 3.16 \\
\hline Nictymene cephalotes & 1 & 1 & 5 & 3 & 1 & 1 & 7 & 5 & 12 & 4.74 \\
\hline Nyctimene minutus & 0 & 0 & 0 & 0 & 1 & 1 & 1 & 1 & 2 & 0.79 \\
\hline Rousettus amplexicaudatus & 7 & 11 & 6 & 8 & 5 & 6 & 18 & 25 & 43 & 17.00 \\
\hline Rousettus celebensis & 6 & 11 & 7 & 7 & 13 & 9 & 26 & 27 & 53 & 20.95 \\
\hline Thoopterus nigrescens & 3 & 7 & 18 & 10 & 3 & 2 & 24 & 19 & 43 & 17.00 \\
\hline Thoopterus sp. & 0 & 1 & 0 & 0 & 0 & 0 & 0 & 1 & 1 & 0.40 \\
\hline Total & 21 & 35 & 56 & 44 & 52 & 45 & 129 & 124 & 253 & 100 \\
\hline Total & \multirow{2}{*}{\multicolumn{2}{|c|}{56}} & \multicolumn{2}{|c|}{100} & \multicolumn{2}{|c|}{97} & & & & \\
\hline$\%$ & & & \multicolumn{2}{|c|}{39.53} & \multicolumn{2}{|c|}{38.34} & & & & \\
\hline
\end{tabular}

Note: PF: Primary Forest; SF: Secondary Forest; AL: Agricultural Land; M: Male; F: Female

Table 2. Ectoparasites, bat species, prevalence, mean abundance, and mean intensity

\begin{tabular}{|c|c|c|c|c|c|c|}
\hline $\begin{array}{c}\text { Ectoparasite } \\
\text { (Family) }\end{array}$ & Bat Species & $\mathbf{N}$ & Infected & $\begin{array}{c}\text { Prevalence } \\
\%\end{array}$ & $\begin{array}{c}\text { Mean } \\
\text { Abundance }\end{array}$ & $\begin{array}{c}\text { Mean } \\
\text { Intensity }\end{array}$ \\
\hline \multirow[t]{8}{*}{ Nycteribiidae } & Cynopterus brachyotis & 63 & 13 & 20.6 & 0.36 & 1.77 \\
\hline & Cynopterus luzoniensis & 23 & 11 & 47.8 & 0.52 & 1.18 \\
\hline & Dobsonia exoleta & 3 & 2 & 66.7 & 2.00 & 3.00 \\
\hline & Macroglossus minimus & 8 & 3 & 37.5 & 0.5 & 1.33 \\
\hline & Rousettus amplexicaudatus & 43 & 39 & 90.7 & 3.42 & 3.77 \\
\hline & Rousettus celebensis & 53 & 40 & 75.5 & 2.43 & 3.23 \\
\hline & Thoopterus nigrescens & 43 & 38 & 88.4 & 3.51 & 3.97 \\
\hline & Thoopterus sp. & 1 & 1 & 100.0 & 2.00 & 2.00 \\
\hline Streblidae & Dobsonia exoleta & 3 & 1 & 33.3 & 0.33 & 1.00 \\
\hline Spinturnicidae & Dobsonia exoleta & 3 & 1 & 33.3 & 1.00 & 3.00 \\
\hline
\end{tabular}


Table 3. Number of Nycteribiid ectoparasites based on the bat gender

\begin{tabular}{|c|c|c|c|c|c|c|c|}
\hline \multirow[t]{2}{*}{ Bat Species } & \multicolumn{2}{|c|}{ Total infected bats/bats } & \multicolumn{2}{|c|}{$\begin{array}{c}\text { Total number of } \\
\text { nycteribiid on bats }\end{array}$} & \multicolumn{2}{|c|}{$\begin{array}{l}\text { Mean intensity } \\
\text { of nycteribiid }\end{array}$} & \multirow{2}{*}{$\begin{array}{c}P \text { - } \\
\text { value }\end{array}$} \\
\hline & $\mathbf{M}$ & $\mathbf{F}$ & $\mathbf{M}$ & $\mathbf{F}$ & M & $\mathbf{F}$ & \\
\hline Rousettus amplexicaudatus & $16 / 18$ & $23 / 25$ & 53 & 94 & $3.31 \pm 1.74$ & $4.08 \pm 2.46$ & 0.29 \\
\hline Rousettus celebensis & $18 / 26$ & $22 / 27$ & 58 & 71 & $3.22 \pm 3.52$ & $2.63 \pm 3.23$ & 0.99 \\
\hline Thoopterus nigrescens & $17 / 19$ & $21 / 24$ & 63 & 88 & $3.71 \pm 2.59$ & $4.19 \pm 2.71$ & 0.58 \\
\hline
\end{tabular}

Note: M: male; F: female

\section{Discussion}

All the bats captured and sampled were small fruit bats belonging to the family Pteropodidae and are often hunted, sold, and consumed by the local community (Ransaleleh et al. 2020). According to the checklist Mammals of Indonesia (Maryanto et al. 2019), four of the species are endemic to Sulawesi, namely D.exoleta, R. celebensis, and Nyctimene minutus with a conservation status of least concern, and $N$. minutus considered as being vulnerable. $N$. cephalotes is found in East Indonesia and the conservation status is least concern, meanwhile, Cynopterus minutus and Macroglossus minimus are spread throughout Indonesia and are also considered least concern. Furthermore, $C$. luzoniensis is distributed in Sulawesi and Philippines with a conservation status of least concern. Cynopterus brachyotis and $R$. amplexicaudatus are spread throughout South East Asia and are also considered least concern. Eight species were infested with nycteribiids (genus Leptocyclopodia) while Streblidae and Spinturnidae were only found on Dobsonia exoleta. Due to lack of specimen, these two families were not identified at the species level.

\section{Composition and ecology of bat species communities in the surveyed habitats}

Six species namely $C$. brachyotis, $R$. amplexicaudatus, $R$. celebensis, T. nigrescens, Nictymene cephalotes, and Macroglossus minimus, were observed in the three surveyed habitat. Cynopterus luzoniensis was found in both secondary forest and agricultural land but not in the primary forest. Dobsonia exoleta was found only in the secondary forest, Nyctimene minutus was only found in the agricultural land. while Thoopterus sp. was found only in the primary forest habitat. Furthermore, the species $C$. brachyotis, $R$. Celebensis, and $R$. Amplexicaudatus, Thoopterus nigrescens live in groups in large tree holes such as Ficus sp., Rotudivolia sp., Livistonia sp., Octomeles sumatrana, Dracontomelon dao, Tetrameles rudiflora and in coastal cliff caves. Cynopterus brachyotis was the most common species observed in the three habitats. Sheherazade et al. (2017) reported that Cynopterus brachyotis constitute one of the most common fruit-eating bats in Southeast Asia. This species occupies a wide variety of habitats including primary, secondary, burnt and mangrove forest, as well as agricultural land areas, and urban (Sheherazade et al. 2017; Lee et al. 2018). The ability to successfully adapt to disturbed environments is one of the key factors that make this species thrive in various types of habitats.
The genera Nictymene, and Macroglossus reportedly lives in trees with large fronds such as woka (Livistona rotundifolia) and banana leaves (Musa sp.). These bats roost under large tree fronds to hide from predators (Chaverri and Kuntz 2010; Lima and O'Keefe 2013), and consume nectar from flowering trees, especially flowering plants such as banana (Musa sp.). Besides, the Dobsonia genus is usually found in cave along the coast (Fatem et al. 2006). Coconut (Cocos nucifera) and palm trees (Arenga pinnata), are very common on agricultural land and provide feeding for the genus Cynopterus and Rousettus bats. The results confirmed the study of Suripto et al. (2006), which reported that Cynopterus and Rousettus frequently visited Arenga pinnata trees to suck the sap. Macroglossus sp. and Nyctymene sp. are solitary bats and nectar feeders, while Thoopterus sp. and Dobsonia feed on fruits, meanwhile, M. minutus frequently visits flowering plants to feed on the nectar (Fukuda et al. 2009).

\section{Ectoparasites identified}

Majority of the sampled species ( 8 of 10) were infested by ectoparasites of the family Nycteribiidae genus Leptocyclopodia, an obligate hematophagous ectoparasite, reported in bats of the Pteropodidae family (Maa 1975; Rajemison et al. 2017; Lee et al. 2018). In Singapore, Leptocyclopodia ferrarii was recorded as monoxenous (parasitizes one host species) ( Lim et al. 2020), however, it was categorized as oligoxenous (parasitizes more than one host of the same genus) in Malaysia (Azhar et al. 2015). The difference in host specificity between these studies is related to host diversity in the ecosystem and co-roosting opportunities and interaction among host species. In BTNP dominated by coastal forest with small caves, secondary, and primary forest vegetation are suitable habitats for a diverse range of small fruit bats compared to Singapore.

In this study, ectoparasites were mostly found on the bats' body $(87.69 \%)$, while ectoparasites on wings and head were less common, $8.28 \%$, and $4.03 \%$ respectively. Also, species with dense fur had larger number of ectoparasites compared to others with thin fur. The abundance, intensity, and prevalence of ectoparasites in bats are influenced by a range of variables including, morphology, habitat (Bush et al. 2013), gender, nesting, grooming (Ramanantsalama et al. 2018) social behavior (Czenze and Broders 2011; Hiller et al. 2020), diet (Luguterah and Lawer 2015) and body size (Rajemison et al. 2017). This also was observed in the results. Furthermore, species that live in groups in tree holes and caves such as Thoopterus sp., Rousettus sp., Cynopterus sp., 
and $C$. brachyotis, had a higher number of ectoparasites compared to Macroglosus minimus, which lives in tree canopy.

The abundance and intensity of ectoparasite infestation varied widely among the studied species. Thoopterus nigrescens had the highest abundance (3.51) and intensity (3.97). This species exhibit roosting communally and use the same locations as permanent roosting sites or for a long time. Nycteriibidae pupate lives in the walls of roost sites (Dick and Dittmar 2014), therefore, permanent roosting site provides stable micro-environmental conditions that favor successful development of parasites (Dube et al. 2018). Moreover, the prevalence of ectoparasite infestation also varied widely, meanwhile, among the bat species with a prevalence value greater than $50 \%$, three species (i.e., $R$. celebensis, $R$. amplexicaudatus, and Thoopterus nigrescens) had severe infestations with values ranging from $75.5-90.7 \%$. The sharing of roosting sites among individual bats and others of different species is the likely factor affecting the prevalence of ectoparasite infestation (Hiller et al 2020). This value was found to be $90.7 \%$ in $R$. amplexicaudatus as also reported by Alvarez et al. (2016) in a research conducted at Lake Naujan National Park, Mindoro Oriental Philippine Province. In addition, the value also indicated that the bat species $R$. amplexicaudatus had heavy infestation, which is applicable as a health indicator (Bush et al. 2013).

Statistical analysis using Boostrap methods showed that there was no significant gender difference among the bat species regarding ectoparasite infestation ( $p$-value $>0.05$ ), although female bats had higher total number of infestation compared to males (Table 3). The vulnerability of female bats to ectoparasites might be due to fluctuations in the reproductive cycle such as pregnancy and lactation, which causes reduced immunity and therefore greater tendency of parasite infestation. Furthermore, female bats spend more time at roosting sites during these periods, increasing the duration and intensity of contact with ectoparasites (Webber et al. 2015). In Singapore, the prevalence rate in male $C$. brachyotis was higher than females (Lim et al. 2020) because mature males participate in roost defense (Archarya et al. 2015). Grooming rates related to the average number of ectoparasites consumed per day did not differ between adult males and females (Ramanantsalama et al. 2018). Meanwhile, given the variation in the literature regarding gender differences in infestation, more research is needed to investigate parasite load related to gender.

Based on the literature search, this study represents the first work to document the fruit bat diversity and the ectoparasites in the boundary areas of the Tangkoko Nature Reserve, specifically Batuputih Nature Tourism Park, hence, it provides important data line base for future reference in monitoring bat population status and conservation efforts in the region. Furthermore, given the close relationship between the local people and bats (e.g., hunting and consumption), more work is needed to address the potential pathogen risks from zoonotic transmissionboth from the bats and the ectoparasites. For example, several studies have reported that the nycteribiid fly (Nycteribia kolenatii) is suspected to play a role in the development of malaria parasites in Chiroptera (Polychromophilus murinus) (Gardner and Molyneux 1988; Witsenburg 2014). In addition, Bartonella was detected in bat ectoparasites such as Streblidae, Nycteribiidae, and Spinturnicidae (Morse et al. 2012; Brook et al. 2014), while arboviruses have been detected in Nycteribiidae by Aznar-Lopez et al. (2013). These examples illustrate the need for further study and continued surveillance to better understand the potential risks that exist and be more proactive in mitigating zoonotic pathogen transmission in Indonesia.

\section{ACKNOWLEDGEMENTS}

The authors gratitude to the head of the North Sulawesi Balai Konservasi Sumber Daya Alam (BKSDA) of the Indonesian Department of Forestry, for their permission to conduct this research and to Carl W. Dick, Ph.D. from the Department of Biology at Western Kentucky University, USA for assisting with the identification of bat flies. The author is also grateful to long-time field guide, Jopie Manderos, for his assistance in the field. This project was supported in part by a Basic Research Grant Number SP DIPA-042.01.2.400959/2018 from Sam Ratulangi University, and the One Earth Institute. RCK's effort was supported in part by the Office of Research Infrastructure Programs (ORIP) of the National Institutes of Health through Grant Number P51OD010425 to the WaNPRC.

\section{REFERENCES}

Almeida J, Silva SSP, Serra-Freire NM, Valim MP. 2011. Ectoparasites (Insecta and Acari) associated with bats in Southeastern Brazil. J Med Entomol 48 (4): 753-757. DOI: 10.1603/ME09133.

Almeida JC, Martins MA, Guedes PC, Peracchi AL, Serra-Freire NM. 2016. New records of mites (Acari: Spinturnicidae) associated with bats (Mammalia, Chiroptera) in two Brazilian biomes: Pantanal and Caatinga. Braz J Vet Parasitol 2 (51): 18-23 DOI: 10.1590/S198429612016005.

Alvarez JDV, Lit IL, Alviola PA, Cosico EA, Eres EG. 2016. A contribution to the ectoparasite fauna of bats (Mammalia: Chiroptera) in Mindoro Island, Philippines: I. Bloodsucking Diptera (Nycteribiidae, Streblidae) and Siphonaptera (Ischnopsyllidae). International Intl J Trop Insect Sci 36 (4): 188-194 DOI: $10.1017 /$ S1742758416000187.

Archarya PR, Racey PR, McNeil D, Sotthibandhu S, Bumrungsri S. 2015. Timing of cave emergence and return in the dawn bat (Eonycteris spelaea, Chiroptera: Pteropodidae) in Southern Thailand. Mammal Stud 40: 47-52. DOI: 10.3106/041.040.0108.

Arrijani, Rizki M. 2020. Vegetation analysis and population of tarsier (Tarsius spectrumgurskyae) at Batuputih Nature Tourism Park, North Sulawesi, Indonesia. Biodiversitas 20 (2): 530-537. DOI: 10.13057/biodiv/d210214.

Azhar I, Khan FAA, Ismail N, Abdullah MT. 2015. Checklist of bat flies (Diptera: Nycteribiidae and Streblidae) and their associated bat hosts in Malaysia. Check List 11 (5): 1777. DOI: DOI: 10.15560/11.5.1777.

Aznar-Lopez C, Vazquez-Moron S, Marston DA, Juste J, Ibanez C, Jose Miguel Berciano JM, Salsamendi E, Aihartza J, Banyard AC, McElhinney L, Fooks AR, Echevarria J. 2013. Detection of Rhabdovirus viral RNA in oropharyngeal swabs and ectoparasites of Spanish bats. J Gen Virol 94: 69-75. DOI: 10.1099/vir.0.046490-0.

Baker EW, Delfinado M D. 1964. Spinturnicidae of South East Asia and the Pacific regioll. Pacific Ins 6: 571-591. 
Bergmans W, Rozendaal FG. 1988. Notes on collections of fruit bats from Sulawesi and some off lying island (Mammalia, Megachiroptera). Zool Verh 248: 1-72.

Brook CE, Bai Y, Dobson AP, Osikowicz LM, Ranaivoson HC, Zhu Q, Kosoy MY, Dittmar K. 2015. Bartonella spp. in fruit bats and bloodfeeding ectoparasites in Madagascar. PLoS Negl Trop Dis 10(2):e0003532. DOI: 10.1371/journal.pntd.0003532.

Bush AO, Lafferty KD, Lotz JM, Shostak AW. 1997. Parasitology meet ecology on its own terms: Mardolis et al. Revisted. J Parasitol 83(4): 573-583. DOI: $10.2307 / 3284227$.

Bush SE, Michelle R, Maher S. 2013. Impact of forest size on parasite biodiversity: Implications for conservation of hosts and parasites Biodivers Conserv 22 (6): 1391-1404. DOI 10.1007/s10531-0130480-x.

Chaverri G, Kunz T. 2010. Ecological determinants of social systems: Perspectives on the functional role of roosting. Adv Stud Behav 42: 275-318. DOI: 10.1016/S0065-3454(10)42009-4

Czenze ZJ, Broders HG. 2011. Ectoparasite community structure of two bats (Myotis lucifugus and M. septentrionalis) from the Maritimes of Canada. J Parasitol Res 2011 (2): 341535 . DOI: 10.1155/2011/34153.

Dick CW, Dittmar K. 2014. Parasitic bat flies (Diptera: Streblidae and Nycteribiidae): Host specificity and potential as vectors. In: Klimpe S, Mehlhorn H (eds). Bats (Chiroptera) as Vectors of Diseases and Parasites. Parasitol Res Monog 5: 131-155. Springer, Berlin. DOI: 10.1007/978-3-642-39333-4 6

Dube WC, Hund AK, Turbek SP, Safran RJ. 2018. Microclimate and hos body condition influence mite population growth in a wild bird ectoparasite system. Intl J Parasitol Parasites Wildl 7: 301-308 DOI: 10.1016. DOI: 10.1016/j.ijppaw.2018.07.007.

Dumont ER, O'neal R. 2004. Food hardness and feeding behavior in Old World fruit bats (Pteropodidae). J Mammal 85 (1): 8-14. DOI 10.1644/BOS-107.

Fatem SM, Bumbut PI, Ungirwalu A. 2006. Habitat of Fruit bat (Dobsonia minor) in Nuni tropical lowland forest of Northern area in Manokwari. Media Konservasi 9 (1): 17-20. [Indonesian]

Fukuda D, Tisen OB, Momose K, Sakai S. 2009. Bat diversity in the vegetation mosaic around a lowland dipterocarp forest of Borneo. Raffles Bull Zool 57(1): 213-221.

Gardner RA, Molyneux DH. 1988. Polychromophilus murinus: A malaria parasite of bats: Life-history and ultrastructural studies. Parasitology 3: 591-605. DOI: 10.1017/s0031182000080215.

Gay N, Olival KJ, Bumrungsri S, Siriaroonrat B, Bourgarel M, Morand S 2014. Parasite and viral species richness of Southeast Asian bats: Fragmentation of area distribution matters. Intl J Parasitol Parasites Wildl 3: 161-170. DOI: 10.1016/j.ijppaw.2014.06.003.

Hiller T, Brandel SD, Honner B, Page RA, Tschapka M. 2020 Parasitization of bats by bat flies (Streblidae) in fragmented habitats Biotropica 52 (3): 488-501. DOI:10.1111/btp.12757.

Holz PH, Lumsden LF, Hufschmida J. 2018. Ectoparasites are unlikely to be a primary cause of population declines of bent-winged bats in South-eastern Australia. Intl J Parasitol Parasites Wildl 7: 423-428. DOI: 10.1016/j.ijppaw.2018.10.006.

Indonesian Ministry of Health Research and Development Agency. 2015 Guidelines for Collecting Reservoir (Bat) Data in the Field. Publisher Indonesian Ministry of Health Research and Development Agency, Jakarta. [Indonesian]

Kim HC, Han SH, Dick CW, Choi YG, Chong ST, Klein TA, Rueda, LM 2012. Geographical distribution of bat flies (Diptera: Nycteribiidae and Streblidae), including two new records, Nycteribia allotopa and $N$. formosana, collected from bats (Chiroptera: Rhinolophidae and Vespertilionidae) in the Republic of Korea. J Vector Ecol 37: 333 337. DOI: $10.1111 /$ j.1948-7134.2012.00235.

Kyes RC, Iskandar E, Paputungan U, Onibala J, Laatung S, Huettman F. 2013. Long-term population survey of the Sulawesi black macaques (Macaca nigra) at Tangkoko Nature Reserve, North Sulawesi, Indonesia. Am J Primatol 75 (1): 88-94. DOI: 10.1002/ajp. 22088.

Latinne A, Suryo S, Kalengkongan J et al. 2020. Characterizing and quantifying the wildlife trade network in Sulawesi, Indonesia. Glob Ecol Conserv 21: e00887. DOI: 10.1016/j.gecco.2019.e00887.

Lee VN, Mendehall IA, Lee BPYH, Posa MRC. 2018. Parasitism by bat flies on an urban population of Cynopterus brachyotis in Singapore. $\begin{array}{llll}\text { Acta } & \text { Chiropt } 20 & \text { (1): } & 177-185 .\end{array}$ 10.3161/15081109ACC2018.20.1.013

Lim ZX, Hitch AT, Lee BPYH, Low DHW, Neves ES, Borthwick, Smith GJD, Mendenhall. 2020. Ecology of bat flies in Singapore: A study on the diversity, infestation bias and host specificity (Diptera:
Nycteribiidae). Intl J Parasitol Parasites Wildl 12 (2020): 29-33 DOI: 10.1016/j.ijppaw.2020.04.010.

Lima SL, O'Keefe JM. 2013. Do predators influence the behaviour of bats? Biol Rev 88: 626-644. DOI: 10.1111/brv.12021.

Luguterah A, Lawer EA. 2015. Effect of dietary guild (frugivory and insectivory) and other host characteristics on ectoparasite abundance (mite and nycteribiid) of chiropterans. Folia Parasitol 62: 021 DOI: $10.14411 /$ fp. 2015.021

Maa TC. 1975. On new Diptera Pupipara from the Oriental Region. Pacific Insect 16 (4): 465-486.

Maryanto I, Maharadatunkamsi, Achmadi AS, Wiantoro S, Sulistyadi E, Yoneda M, Suyanto A, Sugardjito J. 2019. Checklist of the mammals of Indonesia. Puslit Biologi, Bogor. [Indonesian]

Mikail M, Putra TATR, Suri AS, Hezmee MNM, Marina MT. 2017. Preliminary study of Malaysian fruit bats species diversity in Lenggong Livestock Breeding Center, Perak: Potential risk of spillover infection. Vet World 10 (11): 1297-1300. DOI: 10.14202/vetworld.2017.1297-1300.

Mildenstein TL, Tanshi I, Racey PA. 2016. Exploitation of bats for bushmeat and medicine. In: Voigt C, Kingston T (eds.) Bats in the Anthropocene - Conservation of Bats in a Changing World. Springer, New York. DOI: 10.1007/978-3-319-25220-9_12.

Morse SF, Olival KJ, Kossoy M, Billeter S, Pattersen BD, Dick CW, Dittmar K. 2012. Global distribution and genetic diversity of Bartonella in bat flies (Hippoboscoidea, Streblidae, Nycteribiidae). Infect Genet Evol 12 (8): 1717-1723. DOI: 10.1016/j.meegid.2012.06.009.

Mulyono A, Ristiyanto A, Piyiyanti AS, Joharina, Putro DBW. 2018. A new record on fruit bats (Macroglosus sobrinus) as a Leptospirosis reservoir from Indonesia. Vektora 10 (2): 103-110. DOI: 10.22435/vk.v10i2 OKT.581. [Indonesian]

O'Brien TG, Kinnaird MF. 1996. Changing populations of birds and mammals in North Sulawesi. Oryx 30: 150-156. DOI: 10.1017/S0030605300021530.

Pader LMDG, Fiegalan ER, Cruz KGJ. 2018. Chiroptera-associated dipteran ectoparasites (Nycteribiidae, Streblidae) in Minalungao National Park, Nueva Ecija Philippines. J Biodivers Environ Sci 13 (4): 29-37.

Rajemison FI, Lalarivoniaina OSN, Goodman SM. 2017. Bat flies (Diptera: Nycteribiidae, Streblidae) parasitising Rousettus madagascariensis (Chiroptera: Pteropodidae) in the Parc National d'Ankarana, Madagascar: species diversity, rates of parasitism and sex ratios. Afr Entomol 25 (1): 72-85. DOI: 10.4001/003.025.0072.

Ramanantsalama RV, Andrianarimisa A, Raselimanana AP, Goodman SM. 2018. Rates of hematophagous ectoparasite consumption during grooming by an endemic Madagascar fruit bat. Parasites Vectors 11: 330. DOI: 10.1186/s13071-018-2918-1.

Ransaleleh TA, Nangoy MJ, Wahyuni I, Lomboan A, Koneri R, Saputro S, Pamungkas J, Latinne A. 2020. Identification of bats on traditional market in Dumoga district, North Sulawesi. IOP Conf Ser Earth Environ Sci 473 (2020): 012067 DOI: 10.1088/17551315/473/1/012067.

Reeves WK, Beck J, Orlova MV, Daly JL, Pippin K, Revan F, Loftis AD. 2016. Ecology of bats, their ectoparasites, and associated pathogens on Saint Kitts Island. J Med Entomol 53 (5): 1218-1225. DOI: 10.1093/jme/tjw078.

Reiczigel J, Marozzi M, Fabian I, Rozsa L. 2019. Biostatistics for Parasitologists-a primer to quantitative Parasitology. Trends Parasitol 35 (4): 277-281. DOI: 10.1016/j.pt.2019.01.003.

Sheherazade, Tsang SM. 2015. Quantifying the bat bushmeat trade in North Sulawesi, Indonesia, with suggestions for conservation action. Glob Ecol Conserv 3: 324-330. DOI: 10.1016/j.gecco.2015.01.003

Sheherazade, Yasman, Dimas H, Pradana DH, Tsang SM. 2017. The role of fruit bats in plant community changes in an urban forest in Indonesia. Raffles Bull Zool 65: 497-505.

Suripto BA, Sumaryati, Budi C. 2006. The species of fruit bats and their impact on the Coconut "Nira" production in Kokap, Kulon Progo. J Plant Prot Indones 12 (1): 13-24. [Indonesian]

Webber QMR, McGuire LP, Steven B, et al. 2015. Host behaviour, age and sex correlate with ectoparasite prevalence and intensity in a colonial mammal, the little brown bat. Behaviour 152 (1): 83-105. DOI: $10.1163 / 1568539 \mathrm{X}-00003233$.

Webber QMR, Willis CKR. 2016. Sociality, parasites, and pathogens in bats. In: Ortega J (eds). Sociality in Bats. Springer International Publishing, Switzerland. DOI: 10.1007/978-3-3-38953-0-5. 
Witsenburg F. 2014. The Role of Bat Flies (Nycteribiidae) in the Ecology and Ecology of the Blood Parasite Polychromophilus (Apicomplexa: Haemosporida). [Dissertation]. University of Lausanne, Lausanne, Switzerland.

Yang XL, ZhangYZ, Jiang RD, Guo H, Wang BLN, Wang L, Waruhiu C, Zhou JH, Li SY, Daszak P, Wang LF, Shi, ZL. 2017. Genetically diverse Filoviruses in Rousettus and Eonyteris spp. Bats China 2009 and 2015. Emerg Infect Dis 23 (3): 482-486. DOI: 10.3201/eid2303.161119.

Yuliadi B, Sari TF, Handayani FD. 2014. Species of Bats Sulawesi and Their Role in Health. Publishing Institute for Health Research and Development, Ministry of Health of the Republic of Indonesia, Jakarta. [Indonesian]. 